\title{
a \\ KRITIK TERHADAP TEORI DEKONSTRUKSI DERRIDA
}

\author{
Mangihut Siregar \\ Program Studi Magister Ilmu Politik FISIP \\ Universitas Wijaya Kusuma Surabaya
}

Email:msiregar22@yahoo.com

\begin{abstract}
Abstrak
Pemikiran Derrida dipengaruhi pandangan Nietzche, Martin Heidegger dan Freud yang menghilangkan pusat. Derrida melakukan suatu metode yang baru dengan membaca teks dengan menggeser pusat atau inti ke pinggir dan mengubah teks yang dari pinggir ke inti. Metode ini luput dari perhatian strukturalis yang melihat adanya bahasa yang ideal dan maknanya stabil serta pasti. Pembacaan biasa selalu mencari makna yang sebenarnya atau paling benar dari teks tersebut. Derrida mengkritik pandangan ini karena menurutnya dalam setiap teks terdapat makna-makna yang tersembunyi di belakangnya. Melalui teori dekonstruksi, Derrida melihat bahwa teks tidak lagi sebagai tatanan yang utuh melainkan arena pergulatan yang terbuka. Kepastian tunggal yang selalu dicari dan diagung-agungkan manusia modern merupakan suatu keniscayaan. Satu-satunya yang dapat dikatakan pasti hanyalah ketidakpastian. Oleh sebab itu kepastian menurut Derida adalah ketidakpastian. Teori dekonstruksi yang dipopulerkan oleh Derrida memberi pengaruh yang sangat luar biasa dalam ilmu pengetahuan filsafat, bahasa dan juga ilmu-ilmu sosial lainnya. Teori ini tidak pernah puas akan kebenaran yang sudah ada dan selalu curiga akan kemapanan. Dekonstruksi bertujuan mencari hal-hal yang tidak baik dan bukan hal-hal yang baik. Apabila tujuannya mencari yang tidak baik, kapankah tercapai kebaikan atau kemapanan itu?
\end{abstract}

Kata Kunci : dekonstruksi, metode, teori, strukturalis, postrukturalis

\begin{abstract}
The Derrida 's thinking influenced views of Nietzche, Martin Heidegger and Freud who eliminate the central. Derrida use a new method by reading text with shifting the central or core to the edge/margin and change the text from the edge to the core. This method miss from structuralist point of view who see the ideal language and stabil meaning and certainly. Common reading always looking for the truly meaning or most correct from those text. Derrida critics this view according to him in each text found a hidden meaning behind them. Through deconstruction theory, Derrida see that text does any longer as intact/complete order but open wrestle arena. Single certainty always seek and glorified by modern men as necessity only. Therefore certainty according to Derrida adalah is unnecessary. Theory of deconstruction popularized by Derrida convey remarkable influence in philosophy science, linguistic and also other social science. This theory never satisfied on existing truth and always curious to the establishment. Deconstruction purpose seek things that are not good. Whenever the objective seek things does not good, when are the virtue or establishment be reached?
\end{abstract}

Keywords : deconstruction, method, theory, structuralist, poststructuralist 


\section{LATAR BELAKANG}

Istilah dekonstruksi dipopulerkan oleh Jacques Derrida. Pemikiran Derrida berkaitan dengan masalah bahasa yaitu dekonstruksi strukturalisme Saussure juga isu-isu perdamaian dan keadilan yang universal yang hanya menerima satu bentuk keadilan yang selalu dielu-elukan bangsa Barat. Menurut pandangan strukturalisme bahwa bahasa mempunyai makna yang stabil dan pasti. Yang diutamakan bahasa adalah aturan (langue) sedangkan keberagaman bahasa, bentuk bahasa lain (parole) tidak diperlukan. Cara berpikir strukturalisme yang demikian ditentang Derrida dengan istilah dekonstruksi.

Pada awalnya dekonstruksi merupakan cara atau metode membaca teks. Metode dekonstruksi bukan mencari inkonsistensi logis, argumentasi yang lemah seperti yang biasa dilakukan kaum modernisme. Yang dilacak Derrida adalah unsur yang secara filosofis menjadi penentu atau unsur yang memungkinkan teks itu menjadi filosofis. Umumnya dalam setiap teks pemaparannya argumentatif, rasional dan terjalin rapi antara satu sama yang lain. Akan tetapi yang dilacak Derrida bukan penataan yang secara sadar, prosedur yang logis melainkan tatanan yang tidak disadari, yang merupakan asumsi-asumsi tersembunyi yang terdapat di balik teks. Dengan kata lain, Derrida ingin menelanjangi tekstualitas laten dalam sebuah teks.

Melalui dekonstruksi, Derrida menjadi tokoh yang sangat sentral bagi kaum postrukturalis sekaligus postmodernisme. Hal-hal kecil yang kurang diperhatikan kaum strukturalis menjadi pokok perhatian Derrida. Realitas yang dianggap objektif, homogen, singular, didekonstruksi sehingga realitas itu terlihat dengan jelas menjadi plural, heterogen, dan fragmentaris. Melalui dekonstruksinya, Derrida meninggalkan modernisme dan membunuh kedua pahlawan narasi mitos dan logos.

\section{PEMBAHASAN}

Dekonstruksi yang dipopulerkan Derrida pada awalnya merupakan suatu tindakan atau lebih popular suatu metode. Metode dekonstruksi merupakan suatu tindakan dari subjek untuk mempertanyakan, membongkar suatu objek yang tersusun dari berbagai unsur (Noris, 2003: 5). Pembongkaran yang dilakukan merupakan suatu tindakan yang radikal karena berani menghancurkan yang sudah tertata rapi, dianggap paling benar dan sudah diagung-agungkan pada masa itu. Keberanian yang dimiliki dengan argumentasi yang kuat menjadikan Derrida sebagai salah satu tokoh postrukturalis dan postmodernis yang sangat disegani.

Istilah dekonstruksi sangat sulit untuk didefenisikan. Derrida sendiri pun seperti yang pernah ditanyakan seorang wartawan kepadanya mengakui tidak mampu membuat defenisinya (1995: 406). Pernyataan ini membuktikan untuk mendefenisikan dekonstruksi adalah sangat sulit. Untuk itu, dalam tulisan ini akan dicoba membuat suatu defenisi dekonstruksi yang diutarakan oleh Barker (2004: 402) yaitu, memisahkan, membongkar, untuk menemukan dan menelanjangi berbagai asumsi, strategi retoris dan ruang kosong teks. Pengungkapan oposisi biner hierarkis untuk menunjukkan: satu bagian dari pasangan biner tersebut dipandang tidak penting; pasangan biner tersebut menjamin kebenaran; dan masing-masing bagian dari pasangan biner saling berdampak.

Dekonstruksi bukanlah hanya membongkar saja sampai habis dan membiarkannya begitu saja. Seperti yang dikatakan Piliang (2012: 239), agar dekonstruksi berguna untuk kemajuan masyarakat maka diperlukan suatu tindakan baru, tindakan itu disebut rekonstruksi. Rekonstruksi artinya penataan secara terus-menerus struktur, yang juga didekonstruksi secara terus-menerus. Dengan demikian proses dekonstruksi harus 
dilanjutkan oleh rekonstruksi. Penataan bukan hanya sekali dilakukan tetapi secara terus-menerus. Oleh sebab itu dalam dekonstruksi diperlukan tenggang waktu (time span) bagi hidupnya struktur beserta konsensus yang membangunnya. Untuk memahami timbulnya teori dekonstruksi yang dipopulerkan Derida, pembaca harus mengerti sejarah strukturalisme.

\section{BAHASA DAN MAKNA MENURUT KAUM STRUKTURALIS}

Strukturalisme merupakan aliran pemikiran yang berkembang di awal abad XX. Istilah struktur pada awalnya dikenal dalam ilmu alam, misalnya: struktur alam, struktur tubuh, struktur kimia, dan lain-lain. Namun demikian, dalam perkembangan selanjutkan, strukturalisme bukan hanya dikenal dalam ilmu alam tetapi juga berkembang ke ilmu-ilmu sosial dan humaniora. Beberapa tokoh yang juga menganut paham strukturalisme di antaranya: Emile Durkheim dalam ilmu sosiologi, Karl Marx dalam ilmu budaya, Sigmund Freud dalam ilmu psikologi, Claude Levi-Strauss dalam ilmu antropologi, dan Ferdinand de Saussure dalam ilmu linguistik. Pada tulisan ini fokus yang dibahas adalah pendapat Saussure tentang strukturalisme.

Inti dari strukturalisme yaitu adanya sistem atau struktur yang mengatur kehidupan manusia. Sistem merupakan seperangkat bagian-bagian atau unsur-unsur yang saling berkaitan (Lubis, 2014: 38). Bagi strukturalisme yang diutamakan adalah memahami struktur dalam yang tidak terjangkau oleh indra manusia, sedangkan fenomena permukaan dan juga makna yang tersembunyi tidak penting. Makna atau kebenaran ditemukan apabila berhubungan dengan struktur atau sistem bahasa yang digunakan.

Makna diperoleh melalui tanda. Tanda menurut Saussure merupakan kesatuan yang tak dapat dipisahkan dari dua bidang seperti selembar kertas.
Bidang pertama sebagai penanda untuk menjelaskan bentuk atau ekspresi, dan bidang yang kedua merupakan petanda, yaitu menjelaskan konsep atau makna (Piliang, 2012: 349). Penanda sifatnya material dan konkrit yaitu wujud bentuk atau ekspresi bahasa, sedangkan petanda sesuatu yang bersifat abstrak dan tak tertangkap indera yang bertujuan menjelaskan konsep atau makna di balik penanda yang konkrit.

Tanda berhubungan dengan konvensi sosial yang sudah ada dalam masyarakat. Misalnya seseorang menangis tentu karena mengalami kesedihan. Gambaran kesedihan diwujudkan dalam air mata, tanda ini merupakan suatu konvensi sosial yang mengatur pengkombinasian tanda dan maknanya. Hubungan antara penanda dan petanda yang sudah menjadi konvensi sosial ini disebut dengan signifikasi.

Suatu tanda mendapat maknanya disebabkan perbedaannya dengan tanda-tanda lain. Tanda adalah segala sesuatu yang mengandung makna, yang mempunyai dua unsur, yaitu penanda (bentuk) dan petanda (makna). Tanda mobil mempunyai makna sebagai alat untuk transportasi yang mempunyai empat roda berbeda dengan sepeda motor atau beca. Tanda mobil, sepeda motor dan becak ditetapkan begitu saja tanpa diketahui mengapa kenderaan empat roda disebut mobil, kenderaan dua roda disebut sepeda motor dan kenderaan tiga roda disebut beca. Penyebutan ini sudah menjadi konvensi sehingga bahasa sebagai sistem tanda bersifat arbitrer.

Arbitrer merupakan konsep semiotika yang menyatakan bahwa hubungan antara penanda dan petanda hanya berdasarkan kesepakatan sosial dan bukan hubungan alamiah. Suatu tanda mendapat maknanya karena perbedaannya dengan tanda lain. Apabila penanda dan petanda bersifat arbitrer maka hubungan antar kata, antar kalimat dan seterusnya juga bersifat arbitrer. Pandangan kaum modernis ini ditentang oleh Derrida, dengan 
pernyataan bahwa pikiran atau logos tidak pernah berkorespondensi dengan kenyataan, dan klaim kebenaran masih dipertanyakan (Hardiman, 2003: 183).

Logosentrisme merupakan ciri pemikiran Barat dan anti pada mitos. Pada zaman modern, logos menguasai pikiran manusia, di mana manusia mencari dalil-dalil kebenaran yang absolut. Kebenaran absolut yaitu kebenaran yang tunggal, umum dan universal. Dampak dari pemahaman ini adalah pengetahuan yang menindas karena memaksa manusia masuk ke dalam sistem dan menimbulkan dogmatisme dan melegitimasi kekuasaan rasio (Santoso, 2012: 251).

Berbicara tentang tanda, strukturalisme melihatnya sesuatu yang sudah baku dan absolut. Orang yang menangis menandakan kesedihan; orang yang tertawa menandakan kesenangan; orang yang meringis menandakan kesakitan, dan lain-lain. Tidak mungkin orang yang sedih tertawa; tidak mungkin orang yang sehat meringis; dan tidak mungkin orang yang senang menangis. Demikianlah pandangan strukturalisme yang melihat hubungan antara penanda dan petanda selalu sinkron dan sudah baku.

Menurut aliran strukturalis, manusia bukan makhluk yang bebas melainkan makhluk yang terikat oleh struktur yang ada (Lubis, 2014: 50). Segala gerak-gerik manusia sudah terikat dengan struktur sehingga manusia ibarat robot yang bergerak sesuai dengan sistem yang mengendalikannya. Demikian juga dengan bahasa, kemunculannya bukan dari individu-individu melainkan individu berbahasa sesuai dengan struktur yang sudah ada. Dalam pengertian ini struktur itu seakan-akan pemberian Tuhan dan manusia mengikuti atau menerima pemberian itu. Padahal struktur yang ada diawali konstruksi dari individu-individu menjadi suatu yang mapan dan diterima secara bersama.

Strukturalisme melihat gejala hanya mempunyai makna sejauh terhubung dengan gejala lain dalam sebuah struktur sistematis yang tidak berasalmuasal dari pribadi tertentu (Barker, 2014: 273). Makna dalam hal ini bukan hasil dari intensi para subjek pelaku melainkan dari bahasa itu sendiri. Seperti yang diargumentasikan Saussure bahwa makna dihasilkan lewat sebuah sistem perbedaan yang terstruktur sehingga pemaknaan merupakan hasil dari aturan dan konvensi yang mengatur bahasa yang disebut dengan langue. Saussure membedakan langue dengan parole. Langue merupakan seperangkat aturan atau sistem bahasa. Parole merupakan bahasa seperti terwujud dalam tuturan dan tulisan (Lubis, 2014: 54).

Fokus kajian strukturalisme berada pada langue bukan parole. Hal ini terjadi dikarenakan langue berdasarkan atas sistem yang homogen, stabil dan sifatnya objektif sedangkan parole subjektif (Lubis, 2014: 83). Langue merupakan sistem tanda yang sudah baku dan bukan ditentukan oleh subjek tetapi sepenuhnya ditentukan oleh sistem bahasa itu sendiri. Parole mengacu pada penggunaan bahasa seseorang yang membedakan dirinya dengan orang lain. Oleh karena itu parole sifatnya individu, merupakan hasil konstruksi, tidak konvensional dan sifatnya heterogen.

Kaum strukturalis melihat segala keadaan yang terjadi ditentukan oleh struktur. Dunia diibaratkan sebagai suatu sistem yaitu hubungan dari realitas atau benda-benda itu sendiri. Hubungan itu bermakna apabila berhubungan dengan struktur atau sistem dalam keseluruhan (Norris, 2003:9). Individu sudah terkungkung dalam sistem atau aturan yang ada. Setiap orang berbahasa harus sesuai dengan kaidah bahasa umum yang sudah disepakati. Bahasa menjadi pemberian (given) bukan datang dari individu (konstruksi). Bahasa boleh ada disebabkan adanya sistem perbedaan (system of difference) dan intinya adalah oposisi biner (binary opposition).

Oposisi biner merupakan inti dari pemikiran struktural Saussurean. Menurut Lubis (2014: 53), 
oposisi biner merupakan sebuah sistem yang terdiri dari dua kategori yang berelasi, yang dalam bentuknya paling murni membentuk keuniversalan. Menurut pandangan ini, oposisi berjalan berdampingan artinya sesuatu kategori hanya dapat dipahami apabila direlasikan dengan kelompok lain. Contoh dari oposisi itu: penanda/ petanda, tuturan/tulisan, langue/parole, baik/buruk, benar/salah, hadir/absen, makna/bentuk, depan/ belakang, dsb. Pandangan oposisi biner bahwa istilah yang pertama lebih penting (superior) sedangkan yang kedua kurang penting (imperior).

Oposisi biner yang terdapat dalam bahasa hampir sama dengan oposisi biner dalam tradisi filsafat Barat. Karena kesamaan ini sehingga Derrida menyebutnya oposisi biner adalah milik logos atau "kebenaran dari kebenaran" (Norris, 2003: 10). Kebenaran yang dimaksud yaitu yang pertama lebih benar dari yang kedua, dengan pengertian lain istilah yang pertama selalu memiliki keistimewaan sedangkan yang kedua dilecehkan.

Pengertian oposisi biner hampir sama dengan ideologi. Ideologi membuat garis batas yang jelas di antara oposisi konseptual seperti kebenaran dan kekeliruan, pusat dan pinggiran, makna dan tidak bermakna. Menurut Derrida pemikiran ini harus dihancurkan karena satu pengertian tergantung pada pengertian yang lain (Sarup, 2011: 54).

\section{METODE DAN TEORI DEKONSTRUKSI}

Penerapan dekonstruksi yang dilakukan Derrida yaitu menitikberatkan pada hal-hal yang kecil. Hal ini sangat berbeda dengan strukturalisme dan filsafat Barat yang fokus pada pusat (logosentrisme). Menurut Derrida, sesuatu teks selalu ada yang disembunyikan atau ditutup-tutupi (Ritzer, 2004: 205). Untuk menyingkap yang ditutupi itu perlu diadakan suatu cara yaitu dekonstruksi. Dengan demikian dekonstruksi yang dimaksud oleh Derrida bukan untuk mencari kebenaran atau yang paling benar dan menghancurkan yang salah tetapi mendekonstruksi secara terus menerus tanpa henti.

Pandangan yang diutarakan Derrida sangat bertentangan dengan filsafat Barat yang mencari apa yang benar, tepat, indah dan seterusnya. Pandangan ini merupakan logosentrisme yang menyebabkan ketertutupan filsafat dan juga ilmu pengetahuan manusia. Derrida ingin membongkar ketertutupan ini dengan cara membebaskan tulisan dari sesuatu yang memperbudaknya (Ritzer, 2012: 608). Istilah yang digunakan untuk pembongkaran ketertutupan ini adalah dekonstruksi logosentrisme.

Logosentrisme merupakan salah satu ciri dari kaum modernisme. Filsafat modernis mendewakan rasionalis, individualis, dan universalis. Kaum modernis mengagung-agungkan logos dan menjauhkan mitos. Dengan penguasaan logos, kaum modernis berpandangan kehidupan manusia semakin sempurna. Pandangan ini ditolak oleh kaum post-modernisme dengan alasan: pertama, dalam praktiknya, kemajuan-kemajuan yang spektakuler seperti yang diharapkan gagal tercapai; kedua, ilmu pengetahuan modern tidak mampu melepaskan diri dari penyalahgunaan otoritas; ketiga, ada kontradiksi antara teori dan fakta dalam perkembangan ilmu-ilmu modern; keempat, adanya kekeliruan akan anggapan bahwa ilmu pengetahuan modern dapat menyelesaikan segala permasalahan hidup manusia. Dalam kenyataannya, banyak kelaparan, kemiskinan, kerusakan lingkungan akibat turunan dari ilmu pengetahuan dan teknologi; kelima, ilmu-ilmu modern mengesampingkan dimensi-dimensi mistis dan metafisik eksistensi manusia disebabkan lebih mementingkan atribut fisik individu (Santoso, 2012: 248).

Logosentrisme menurut Derrida sekurangkurangnya memiliki dua ciri yaitu, pertama, prosedur-prosedur yang sudah ada harus diakui sebagai suatu orientasi yang paling umum; dan yang kedua, prosedur-prosedur yang sudah ada 
harus diakui sebagai suatu orientasi yang paling umum; dan yang kedua, prosedur-prosedur yang sudah ada harus diterima secara umum dan tidak perlu lagi dipertanyakan atau dipermasalahkan (Hadiwinata, 1994: 23). Apabila prosedur-prosedur yang sudah ada harus diakui dan tidak perlu lagi dipertanyakan, berarti manusia itu tidak perlu membuat inovasi-inovasi. Kebenaran itu tunggal, sudah mutlak, berlaku umum dan sudah final. Kebenaran yang seperti ini sangat berbahaya karena akan menyembunyikan kepentingan kekuasaan antara yang satu dengan yang lain.

Salah satu contoh dari pemikiran Derrida tentang logosentrisme yaitu teater kekejaman (theatre of cruelty). Konsep ini dia bandingkan dengan teater tradisional yang didominasi oleh logika berpikir representasional. Apa yang terjadi di pentas mewakili apa yang terjadi dalam kehidupan nyata (Ritzer, 2012: 608). Suatu teater akan diperankan oleh beberapa pemeran, baik pemeran utama, pemeran tambahan dan yang paling penting adalah skenario dan sutradara. Semua peran diatur sesuai dengan skenario yang sudah ditentukan sutradara. Pertunjukan yang demikian ditentukan oleh sutradara yang mengatur, mengawasi dan menciptakan makna peran yang dimainkan pemerannya. Sutradara sama dengan penguasa sedangkan pemeran sama dengan budak interpretif (interpretive slave) yang sudah ditakdirkan tuannya (Derrida, 1979: 235).

Pertunjukan dipentas menurut pandangan strukturalis merupakan gambaran kehidupan nyata. Hal ini ditentang oleh Derrida, di mana lakon yang diperankan para pemain tidak secara otomatis merepresentasikan kehidupan di masyarakat. Apa yang terjadi di pentas hanyalah keinginan pemesan atau penulis naskah (sutradara), belum tentu sama kenyataannya di masyarakat. Derrida menginginkan timbul suatu pentas di mana panggung tidak dikuasai oleh sutradara tetapi aktor bebas memerankan keinginannya tanpa ada yang mengaturnya (Ritzer,
2012: 609). Dari pernyataan ini terlihat Derrida ingin membebaskan masyarakat dari perbudakan logosentrisme. Derrida menginginkan masyarakat bebas dari kekuasaan penguasa intelektual yang menciptakan pemikiran dominan. Melalui kebebasan yang dimiliki, sehingga semua masyarakat menjadi penulis yang merdeka.

Manusia diharapkan selalu menciptakan inovasi-inovasi baru dan selalu mempermasalahkan kebenaran. Kebenaran tidak harus dibatasi dalam kebenaran tunggal, umum, dan universal melainkan bersifat plural, partikular, dan relatif. Adanya kebenaran yang plural menjadikan suatu kejadian ditafsirkan setiap manusia dengan berbagai tafsiran. Makna dimaknai dengan bermacam makna. Tanda tidak selalu berhubungan antara penanda (bentuk) dengan petanda (makna).

Ketidak setujuan Derrida akan pandangan kaum strukturalisme sangatlah beralasan. Menurut kaum strukturalisme, tanda merupakan kesatuan yang tak dapat dipisahkan dari dua bidang seperti selembar kertas. Bidang pertama sebagai penanda untuk menjelaskan bentuk atau ekspresi, dan bidang yang kedua merupakan petanda, yaitu menjelaskan konsep atau makna (Piliang, 2012: 349). Penanda sifatnya material dan konkrit yaitu wujud bentuk atau ekspresi bahasa, sedangkan petanda sesuatu yang bersifat abstrak dan tak tertangkap indera yang bertujuan menjelaskan konsep atau makna di balik penanda yang konkrit.

Kaum strukturalis melihat tanda itu baku dan tunggal. Orang yang menangis dipastikan karena perasaannya sedih, dan orang yang senyum berarti senang. Dalam kehidupan sehari-hari sering orang menangis bukan karena sedih melainkan karena senang atau terharu. Contoh ini sering terlihat apabila orang yang sudah lama berpisah karena sesuatu hal, dan pada suatu waktu mereka saling bertemu. Orang seperti ini sering untuk menunjukkan kesenangannya atau keterharuannya saling berpelukan dan menangis. Penanda menangis 
bukan hanya petanda kesedihan melainkan sudah menjadi kesenangan. Menangis menurut pandangan kaum strukturalis hanya sebagai petanda kesedihan, namun dalam empiriknya bukanlah demikian. Penanda menangis bukan hanya petanda kesedihan tetapi juga petanda kesenangan. Dalam hal ini makna menangis bukan tunggal, boleh sedih, senang, kepura-puraan, bermain peran, dan lain-lain.

Contoh yang lain mengenai tanda yaitu warna lampu lalu lintas di perempatan jalan atau sering disebut lampu merah. Warna lampu di perempatan ada tiga yaitu, merah, kuning, dan hijau. Ketiga warna tersebut mempunyai makna tersendiri sesuai dengan konvensi, merah berhenti, kuning hati-hati, dan hijau jalan kira-kira demikian pengertian masyarakat umumnya tentang rambu lalu lintas yang ada di perempatan jalan. Dalam pengertian kaum struktural, ketiga tanda itu sudah baku dan tidak boleh diganggu gugat lagi.

Dalam kehidupan sehari-hari ketiga tanda di atas (merah, kuning, dan hijau) bukan hanya menunjuk pada satu tanda. Tanda merah menurut pandangan kaum struktural harus berhenti, apabila ada yang berjalan terus padahal lampu sudah berwarna merah berarti suatu tindakan pelanggaran. Orang yang melanggar rambu lalu lintas akan ditilang. Secara empirik banyak orang yang tidak berhenti walau lampu sudah menandakan merah, misalnya mobil ambulan, pemadam kebakaran, polisi yang menjalankan tugas, dan lain-lain. Mereka tidak pernah ditilang karena bukan melanggar lalulintas. Oleh sebab itu tanda merah dalam lampu lalu lintas bukan hanya harus berhenti tetapi ada tanda yang lain. Benarlah yang dikatakan Derida, selalu saja ada celah di antara penanda dan petanda, antara teks dan maknanya. Pencarian makna absolut merupakan suatu kemustahilan. Pencarian makna selalu berupa jejak setelah jejak, istilah yang dipergunakan Derrida (signifier of signifier) penanda dari pada penanda (Piliang, 2012: 124).
Menurut Derrida, penanda (signifier) tidak berkaitan langsung dengan petanda (signified). Penanda dengan petanda tidak memiliki korespondensi secara langsung. Hal ini sangat bertentangan dengan pendapat Saussure yang menyatakan bahwa penanda berkaitan langsung dengan petanda. Menurut Saussure hubungan antara penanda dan petanda ibarat dua sisi mata uang yang sama. Derrida tidak setuju akan pernyataan ini, menurutnya tanda sebagai struktur perbedaan, sebagian darinya selalu "tidak di sana" sebagian lagi selalu "bukan yang itu". Penanda dan petanda terus berpisah dan menyatu kembali dengan kombinasi-kombinasi baru (Lubis, 2014: 90). Hal ini dapat dilihat melalui contoh kata (tanda) di kamus. Kata yang ada di kamus merujuk pada tanda lain, dan tanda lain merujuk lagi ke tanda lain, begitu seterusnya. Oleh sebab itu suatu penanda akan terus berubah menjadi suatu petanda, dan sebaliknya suatu petanda akan berubah menjadi suatu penanda. Dengan demikian tidak akan pernah suatu penanda sampai kepada petanda akhir (Sarup, 2003: 54).

Mengenai bahasa, kaum strukturalis melihat bahwa setiap individu tidak memiliki kebebasan untuk berbahasa. Hal ini terjadi karena individu berbahasa sesuai dengan sistem atau aturan bahasa yang ada, setiap orang hanya mengikuti aturan tersebut. Untuk itu Ferdinand de Saussure membedakan antara langue dengan parole. Perbedaan langue dengan parole sebagai berikut (Lubis, 2014: 82 - 83):

\section{A. Sifat-sifat langue adalah:}

1. Berada dalam bentuk keseluruhan kesan yang tersimpan dalam otak setiap orang, tetapi tidak terpengaruh oleh kemampuan penyimpannya.

2. Produk sosial dari kemampuan bahasa dan juga merupakan keseluruhan konvensi yang ditentukan kelompok sosial yang memungkinkan untuk menggunakan kemampuan itu. 
3. Langue bersifat pasif karena merupakan hasil penerimaan seseorang dari orang lain yang ada dalam masyarakat, sedangkan parole bersifat aktif.

4. Langue merupakan hasil kesepakatan atau konvensi.

B. Sifat-sifat Parole adalah:

1. Parole selalu bersifat individual, bervariasi, berubah-ubah dan dapat mengandung hal-hal yang baru. Parole tidak mengenal sistem sehingga tidak dapat dikaji secara ilmiah berdasarkan pendekatan positivisme ilmiah atau melalui metode strukturalisme.

2. Parole terjadi dari pilihan individual (unik, khas) yang tidak terhitung jumlahnya.

3. Parole bukan kolektif, semua wujud dan pengungkapannya bersifat sesaat dan heterogen dan merupakan perilaku individu.

Kaum strukturalisme hanya tertarik untuk mengkaji langue sebagai objek kajiannya dikarenakan langue didasarkan atas sistem yang homogen, stabil dan bersifat objektif, sedangkan parole diabaikan. Melalui struktur (aturan gramatikal) kaum strukturalisme merasa menemukan pemaknaan bahasa. Makna bahasa tidak berkaitan dengan realitas eksternal. Setiap individu yang berbahasa hanya sekedar mengikuti struktur bahasa yang sudah ada pada alam bawah sadarnya sehingga individu tidak mempunyai kebebasan dalam berbahasa. Derrida menentang pandangan strukturalisme yang melihat adanya struktur yang stabil, makna yang universal. Derrida dan juga kaum post-struktural lainnya bukan hanya terfokus pada langue justru memberi ruang pada parole (Lubis, 2014: 84).

Pemikiran Derrida akan parole dapat dilihat akan sikap masyarakat dalam pemaknaan lampu tanda lalu lintas seperti yang sudah dijelaskan di bagian atas. Menurut kaum strukturalisme, tanda warna kuning dalam rambu lalu lintas adalah hati-hati dengan kata lain pengemudi harus memperlambat kendaraannya. Namun demikian apabila diperhatikan perilaku setiap pengemudi dalam memaknai lampu warna kuning, ada berbagai macam. Sekelompok orang memaknai warna kuning hati-hati dan mengurangi kecepatan kendaraannya. Sekelompok lain memaknainya biasa saja, yang penting belum warna merah jalan terus seperti biasa. Sementara kelompok lain mempercepat laju kendaraannya mumpung masih warna kuning. Kesempatan yang tinggal sedikit sebelum warna merah sehingga pengemudi memacu kendaraannya semaksimal mungkin. Pemaknaan yang bermacammacam ini mengakibatkan perilaku yang bermacam-macam pula. Hal-hal yang demikian sangat diperhatikan Derrida yang luput dari kajian strukturalisme.

Pemikiran yang lain yang diutarakan Derrida untuk menjelaskan dekonstruksi yaitu dikotomi kehadiran dan absen. Kedua keadaan itu (hadir dan absen) tidak mungkin terlaksana secara bersamaan. Apabila hadir berarti tidak mungkin absen dan begitu juga sebaliknya. Pemikiran Barat pada umumnya lebih menghargai hadir daripada absen. Pemikiran ini dihubungkan dengan konsep berbicara lebih unggul daripada menulis (Zehfuss, 2013: 186). Berbicara dipandang lebih penting dari menulis karena orang yang berbicara hadir secara langsung dengan pendengar. Pembicara dapat melihat bagaimana respon pendengar akan informasi yang disampaikan. Demikian juga sebaliknya, pendengar dapat melihat pembicara baik gaya berbicara, gestur tubuh, emosi dan intonasi yang dilakukan. Apabila pendengar kurang memahami apa yang disampaikan pembicara, pendengar boleh menanyakan atau meminta untuk diulangi apa yang dimaksud pembicara.

Berbeda dengan pembicara yang hadir dalam pembicaraan, penulis tidak perlu hadir untuk menyampaikan maksudnya kepada pembaca. Maksud penulis cukup diwakilkan melalui sebuah tulisan, email, whatsApp, SMS, dan lain-lain. 
Kelebihan dari tulisan ini, si penulis tidak harus hadir dalam pembicaraan, sedangkan kelemahannya maksud dari penulis sering berbeda dengan penafsiran pembaca. Melalui argumentasi ini, berbicara sepertinya lebih baik daripada menulis. Pembicara dan pendengar sama-sama hadir dalam waktu yang sama dan tempat yang sama. Melalui kehadiran tersebut kedua belah pihak dapat saling mengerti apa yang mereka bicarakan.

Bahasa lisan di Barat diasumsikan sebagai wakil atau representasi dari diri-batin atau dapat dikatakan jiwanya makna. Pemikiran yang menganggap bahwa makna-makna bisa hadir dalam interaksi manusia merupakan prinsip yang ada pada pusat (center) yang ditentang Derrida. Oleh sebab itu tulisan merupakan satu bentuk komunikasi di mana makna-maknanya selalu ditunda. Makna yang hadir dalam tanda-tanda dan mitos-mitos dan struktur-struktur yang menghasilkan makna-makna justru selalu absen dari kinerja komunikasi (Chaffee, 2012: 208).

Pemahaman Barat yang menyatakan berbicara lebih baik daripada menulis ditentang oleh Derrida. Menurut Derrida (1998: 43), berbicara dan menulis tidak jauh berbeda. Kedua kata itu sama-sama membentuk apa yang disebutnya sistem menulis pada umumnya (system of writing in general). Dengan kata lain bahwa berbicara merupakan sebuah bentuk tulisan pada umumnya, yaitu sistem untuk merekam dan dengan demikian menghasilkan makna (Zehfuss, 2013: 188).

Tulisan merupakan bentuk permainan bebas dari unsur-unsur bahasa dan komunikasi. Dalam bahasa makna akan berproses secara terus menerus dan tidak akan pernah sampai kepada kebenaran mutlak (logos). Derrida melihat bahwa tulisan merupakan jejak, bekas-bekas tapak kaki yang harus ditelusuri terus menerus sampai menemukan siapa yang empunya kaki. Proses berpikir, menulis dan berkarya berdasarkan jejak inilah yang disebut Derrida sebagai differance (Norris, 2003: 11).
Differance berasal dari kata Perancis di mana pengucapannya persis sama dengan difference. Differrance berasal dari kata differer, yakni: to differ yang berarti membedakan, to defer yang berarti menunda. Di satu sisi differance merujuk pada sesuatu yang menjadi lain, yang tidak sama, yang bisa dibedakan. Pengertian yang lain yaitu menunda atau suatu jalan memutar (Zehfuss, 2013: 189). Differance menghasilkan differences (perbedaan), sehingga memungkinkan adanya dikotomi. Tanda seperti yang dikatakan Derrida (1982: 9) merepresentasikan kehadiran sesuatu itu dalam ketidakhadirannya. Pada saat sesuatu itu tidak dapat ditunjukkan, kita menelusuri jalan memutar dari sign itu. Sign menangguhkan kehadiran, tidak ada yang sekedar hadir atau tidak hadir. Yang ada menurut Derrida adalah differences (perbedaan) dan traces of traces (jejak dari jejak).

Proses differance yang dijelaskan Derrida merupakan penolakan terhadap makna atau petanda yang absolut, makna transendental, makna universal yang diklaim Saussure dan juga kaum strukturalis. Differance adalah permainan perbedaan-perbedaan, jejak-jejak dari perbedaan-perbedaan, penjarakan (spacing) yang dengan cara itu unsur-unsur dikaitkan satu sama lain (Norris, 2003: 11). Oleh karena itu petanda absolut akan selalu berupa jejak dan di belakang jejak ada jejak, demikian seterusnya. Kebenaran mutlak merupakan suatu kemustahilan, yang pasti menurut Derrida ketidakpastian, permainan. Semuanya harus ditangguhkan sambil bermain bebas dengan perbedaan.

\section{KRITIK TERHADAP TEORI DEKONSTRUKSI}

Dari uraian di atas terlihat bagaimana Derrida menghancurkan pandangan yang mengangungagungkan logos dan pusat pada masyarakat modern. Modernisme yang diharapkan dapat 
menyelesaikan masalah kehidupan manusia ternyata dalam praktiknya gagal, tidak berhasil seperti yang diharapkan. Derrida berhasil membunuh mitos sekaligus menguburkan logos.

Namun demikian timbul pertanyaan lebih lanjut akan dekonstruksi Derrida: pertama, menurut Derrrida, berbicara dan menulis tidak jauh berbeda. Keduanya sama-sama membentuk apa yang disebutnya sistem menulis pada umumnya (system of writing in general). Berbicara merupakan sebuah bentuk tulisan pada umumnya, yaitu sistem untuk merekam dan dengan demikian menghasilkan makna. Tulisan merupakan bentuk permainan bebas dari unsur-unsur bahasa dan komunikasi. Dalam bahasa makna akan berproses secara terus menerus dan tidak akan pernah sampai kepada kebenaran mutlak (logos).

Derrida melihat bahwa tulisan merupakan jejak, bekas-bekas tapak kaki yang harus ditelusuri terus menerus sampai menemukan siapa yang empunya kaki. Proses berpikir, menulis dan berkarya berdasarkan jejak inilah yang disebut Derrida sebagai differance. Melalui proses differance, Derrida menolak adanya makna absolut, makna transendental, makna universal seperti yang dipahami kaum strukturalisme. Apabila makna bebas ditafsir setiap orang maka dapat dikatakan tidak ada makna. Makna selalu ditunda dengan demikian segala sesuatu tidak bermakna. Dekonstruksi yang dilahirkan Derrida melahirkan persoalan baru berbentuk: indeterminasi, dan ketidakpastian makna.

Kedua, penerapan dekonstruksi yang dilakukan Derrida yaitu menitikberatkan pada hal-hal yang kecil. Hal ini sangat berbeda dengan strukturalisme dan filsafat Barat yang fokus pada pusat (logosentrisme). Menurut Derrida, sesuatu teks selalu ada yang disembunyikan atau ditutup-tutupi. Untuk menyingkap yang ditutupi itu perlu diadakan suatu cara yaitu dekonstruksi. Dengan demikian dekonstruksi yang dimaksud oleh Derrida bukan untuk mencari kebenaran atau yang paling benar dan menghancurkan yang salah tetapi mendekonstruksi secara terus menerus tanpa henti. Tujuan dekonstruksi adalah mencari kekurangan, ketidakadilan, kebohongan dan lain-lain yang tidak diinginkan masyarakat. Apabila kekurangan yang selalu dicari-cari, kapan tercapai ketenangan, keteduhan, kenyamanan dalam masyarakat?

\section{KESIMPULAN}

Dekonstruksi yang dipopulerkan Derrida menjadi suatu metode sekaligus teori kritis. Derrida menjungkirbalikkan pandangan positivisme dan kebudayaan modern yang mengangungagungkan filsafat atau logos. Terlebih terhadap penganut strukturalisme yang menganggap manusia tunduk terhadap sistem atau struktur yang ada. Segala gerak-gerik manusia diatur oleh struktur yang sudah ada. Struktur seakan-akan benda hidup yang sanggup mengendalikan kehidupan manusia. Struktur menjadi pemberian (given) dan manusia hanya menerima.

Derrida mengkritik pandangan strukturalisme dan ingin membebaskan masyarakat dari perbudakan logosentrisme. Derrida menginginkan masyarakat bebas dari kekuasaan penguasa intelektual yang menciptakan pemikiran dominan. Melalui kebebasan yang dimiliki, sehingga semua masyarakat menjadi penulis yang merdeka.

Walaupun dekonstruksi yang dipopulerkan Derrida sangat membawa dampak yang luar biasa bagi ilmu-ilmu sosial secara umum, namun teori ini juga mempunyai kelemahan. Kebebasan yang dimiliki setiap orang untuk menafsir makna sehingga makna selalu tertunda dengan kata lain tidak ada makna dan tidak ada kepastian. Makna atau kebenaran atau apapun istilahnya selalu tertunda bahkan relatif. Selain itu, kelemahan yang lain yaitu sangat sulit ditemukan ketenangan, keteduhan 
dan kenyamanan karena segala sesuatu tanpa henti-henti selalu didekonstruksi.

\section{DAFTAR PUSTAKA}

Barker, Chris. 2004. Cultural Studies: Teori \& Praktik. Nurhadi (Pentj.). Yogyakarta: Kreasi Wacana.

Barker, Chris. 2014. Kamus Kajian Budaya. B. Hendar Putranto (Pentj.). Yogyakarta: PT Kanisius.

Chaffee, Daniel dan Charles Lemer. 2012. "Strukturalisme dan Post-strukturalisme". Dalam Turner, Bryan S. (ed). Teori Sosial: Dari Klasik Sampai Postmodern. E. Setiyawati A. dan Roh Shufiyati (pentj.). Yogyakarta: Pustaka Pelajar.

Derrida, Jacques. 1978. Writing and Difference. Chicago: University of Chicago Press.

Derrida, Jacques. 1982. Margins of Philosophy. Alan Bass (Pentj.). Chicago: The University of Chicago Press.

Derrida, Jacques. 1995. Points .....Interviews, 1974-1994, ed. Elisabeth Weber, Peggy Kamuf dan kawan-kawan (Pentj). Stanford: Stanford University Press.

Derrida, Jacques. 1998. Of Grammatology. Gayatri Chakravorty Spivak (pentj.), edisi koreksi. Baltimore: The Johns Hopkins University Press.

Hadiwinata, Bob Sugeng. 1994. "Theatrum Politicum: Postmodernisme dan Krisis Kapitalisme Dunia”. Dalam Jurnal Kebudayaan Kalam. No. 1 Th. 1994. Jakarta: Yayasan Kalam dan Penerbit Pustaka Grafiti.

Hardiman, F. Budi. 2003. Melampaui Positivisme dan Modernitas: Diskursus Filosofis tentang Metode Ilmiah dan Problem Modernitas. Yogyakarta: Kanisius.

Lubis, Akhyar Yusuf, 2014. Teori dan Metodologi: Ilmu Pengetahuan Sosial Budaya Kontemporer. Jakarta: PT. Raja Grafindo Perkasa.

Norris, Christopher, 2003. Membongkar Teori Dekonstruksi. Inyiak Ridwan Muzir (Pentj.). Yogyakarta: Penerbit Ar-ruzz.
Piliang, Yasraf Amir. 2012. Semiotika dan Hipersemiotika: Kode, gaya \& matinya makna. Bandung: Matahari.

Ritzer, George. 2004. Teori Sosial Postmodern. Muhammad Taufik (Pentj.). Yogyakarta: Kreasi Wacana.

Ritzer, George \& Douglas J. Goodman. 2012. Teori Sosiologi Modern. Jakarta: Kencana.

Santoso, Heri. 2012. "Metode Dekonstruksi Jacques Derrida: Kritik atas Metafisika dan Epistemologi Modern". Dalam Santoso, Listiyono, dkk. Epistemologi Kiri. Yogyakarta: Ar-Ruzz Media.

Sarup, Madan. 2003. Post-Structuralism and Post-Modernism: Sebuah Pengantar Kritis. Medhy Aginta Hidayat (Pentj.). Yogyakarta: Jendela.

Sarup, Madan. 2011. Panduan Pengantar untuk Memahami Postrukturalisme \& Posmodernisme. Medhy Aginta Hidayat (Pentj.) Yogyakarta: Jalasutra.

Zehfuss, Maja. 2013. "Jacques Derrida”. Dalam Jenny Edkins - Nick Vaughan Williams (ed). Teori-teori Kristis: Menantang Pandangan Utama Studi Politik Internasional. Teguh Wahyu Utomo (Pentj.). Yogyakarta: Pustaka Pelajar. 